\title{
RHETORIC AND FAIR PLAY \\ THE CULTURAL BACKGROUND OF LEGAL ETHICS
}

\author{
Paolo Moro*
}

\begin{abstract}
The duties of diligence and fairness of advocacy derive from the same ethical principle and are realized through two regulated activities: Rhetoric as art of diligence and fair play as art of sportsmanship. Rhetoric and fair play hide two relevant distortions in the legal practice and in the sports competition: The eristic argumentation and the gamesmanship strategy. The obligation of loyalty imposes to the lawyers a rhetorical dialogue in every legal proceeding and it prescribes to keep the relationship between opponents on a real level of equity. Just as the good athlete defends the team colors acting loyally in a race, so the good lawyer protects the dignity of his client not only by a diligent technique but also by fair tactics.
\end{abstract}

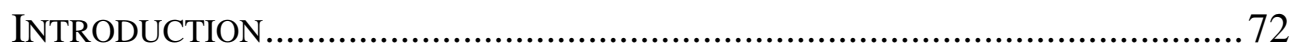

I. LEGAL ETHICS BETWEEN DILIGENCE AND FAIRNESS .............................. 73

II. RHETORIC AS ART OF DILIGENCE .................................................... 75

III. FAIR PLAY AS ART OF SPORTSMANSHIP ........................................ 77

IV. LEGAL ETHICS BETWEEN ERISTIC AND GAMESMANSHIP ....................... 81

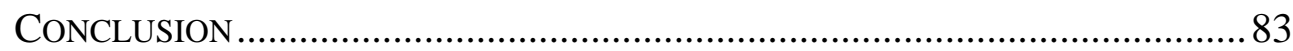

\section{INTRODUCTION}

According to every own code of legal ethics, the lawyers' first duty is to act upon diligence and fairness in relations with judge, clients and colleagues, and ethical prescriptions appear to be all ascribable to these guidelines.

These principles are widely recognized in America and in Europe, whose legal systems governing differently the activity of lawyers, but on common rules.

Indeed, the Model Rules of Professional Conduct, established by the American Bar Association (ABA) ${ }^{1}$, states that "a lawyer shall act with reasonable diligence and promptness in representing client" (Rule 1.3) and also that he has to respect "fairness to opposing party and counsel" (Rule

\footnotetext{
${ }^{*}$ Full Professor of Philosophy of Law, Department of Private Law and Critique of Law, University of Padova, Italy; Member of the Integrity Research Group (IRG) of the Kingston University Law School of London, UK; Lawyer in the Court. Research fields: Legal Rhetoric, Legal Ethics, Sports Law, Philosophy of Law.

${ }^{1}$ ABA Model Rules of Professional Conduct (1983),

http://www.americanbar.org/groups/professional_responsibility/publications/model_rules_of_professi onal_conduct.html.
} 


\section{4).}

In the comment of the first rule, the American Bar Association declares that 'the lawyers' duty to act with reasonable diligence does not require the use of offensive tactics or preclude the treating of all persons involved in the legal process with courtesy and respect".

In the comment of rule 3.4, appears that "fair competition in the adversary systems is secured by prohibitions against destruction or concealment of evidence, improperly influencing witnesses, obstructive tactics in discovery procedure, and the like".

Furthermore, the Code of Conduct for European Lawyers of the Council of Bars and Law Societies of Europe $(\mathrm{CCBE})^{2}$ provides that "a lawyer shall advise and represent the client promptly, conscientiously and diligently" (article 3.1.2) and that "a lawyer must always have due regard for the fair conduct of proceedings" (article 4.2).

In the comment of article 3.1.2, the CCBE notes that "the lawyer cannot avoid responsibility by delegation to others", after stating that "a relationship is maintained between lawyer and client".

In the comment of article 4.2, it can read that "in adversarial proceedings a lawyer must not attempt to take unfair advantage of his or her opponent" and that "the lawyer must not, for example, make contact with the judge without first informing the lawyer acting for the opposing party (...)".

Nevertheless, the duties of diligence and fairness does not cause a "divided loyalty" of advocacy between the zealous partisanship and the respect of positive law, because both notions derive from the same ethical principle.

\section{LEGAL ETHICS BETWEEN DILIGENCE AND FAIRNESS}

Currently, we note a kind of osmosis of the traditional two-faced obligations of lawyers in some considerable conceptions of the legal ethics debate.

On one hand, advocacy realizes true diligence when the lawyer is the voice of dignity of his client, who has the possibility to defend his personal and unrepeatable story in the procedural debate, explaining his viewpoint ${ }^{3}$.

In this sharable perspective, human dignity is not identified by the

\footnotetext{
${ }^{2}$ CODE OF CONDUCT FOR European LAWYers (1988), http://www.ccbe.eu/NTCdocument/EN_CCBE_CoCpdf1_1382973057.pdf.

${ }^{3}$ D. Luban, Lawyers as Upholders of Human Dignity (When They Aren't Busy Assaulting it), 3 UNIVERSITY OF ILLINOIS LAW REVIEW, 815-845 (2005).
} 
modern notion of autonomy, that is willing or choosing, but it describes the whole human being, which includes perceptions, reflections and generally every relationship with another.

Then, the presence of lawyer is highly necessary to protect the dignified speech of a defendant in the due process of law, where the adversarial system demands a professional intervention to bring out the story of someone versus another one.

On the other hand, the obligations of competence and diligence must always be exercised by the lawyers within the law, that is not an inconvenient obstacle to be worked around but it confers rights and duties upon their clients ${ }^{4}$.

According to this significant conception, fidelity to law doesn't mean abandoning the client and becoming an authority servant, but it's a sort of loyalty that implies a correct use of legal system by a "simply zealous" lawyer to satisfy the client's interest in the best way ${ }^{5}$.

Remarkable appears also the attempt to restrict the professional discretion developing a "philosophy of lawyering", that operates at three interrelated and normative levels of regulation: The personal, the practice and the institutional ${ }^{6}$.

Finally, a theoretical model has tried to elaborate a perspective of the lawyers acting as intermediaries between clients and law ${ }^{7}$, interpreting the exigency of a rational foundation of the lawyer-client relation.

Likewise, the independence of the lawyer derives not only from the legal knowledge, but also from the technical expertise: Counselor or litigator can and must choose the best possibility in a negotiation or in a legal proceeding to exercise a right or to apply the law. And the technical capability draws the line of discretion in advocacy, disclosing the lawyers' fairness among the protection of the client and the dialogue with the judge.

Therefore, a limit of the legal profession appears in the zealous effort to gain an unfair advantage for the client, and it happens, for instance, in the abuse of process. Similarly, in the European doctrine of abuse of rights, typical of the civil law systems, the exercise of a right is not permitted when it causes harm or when this way of acting is against elementary fairness ${ }^{8}$.

\footnotetext{
${ }^{4}$ W. B. Wendel, Lawyers ANd Fidelity to Law (Princeton, Princeton University Press 2010).

${ }^{5}$ T. Dare, The Counsel of Rogues? A DeFence of THE Standard Conception OF THE LAWYer's Role (Farnham, Surrey, 2009).

${ }^{6}$ N. M. Crystal, Developing a Philosophy of Lawyering, 14 Notre Dame Journal of Law, Ethics \& PuBLIC POLICY 75-101 (2000).

${ }^{7}$ K. R. Kruse, The Jurisprudential Turn in Legal Ethics, 53 ARIzONA LAW REview 493-531 (2011).

${ }^{8}$ R. DE la Feria \& S. Vogenauer, The Prohibition of Abuse of LaW-A New General Principle OF EU LAW? (Oxford: Hart Publishing, 2011).
} 
Thus, in the legal profession, diligence and fairness are opposite poles attracting each other. These principles found the cultural fit of a lawyer and are realized through two regulated activities used concurrently by litigators or barristers in a legal proceeding or by counselors or solicitors in a legal advice: Rhetoric as art of diligence and fair play as art of sportsmanship.

\section{RHETORIC AS ART OF DILIGENCE}

Greek philosophy hands down that Rhetoric is the best method to combat the "battle of words" (logomachia) and to argue faithfully to defend himself in a judicial controversy.

Rhetoric is originally an art of diligence and public communication in the legal proceedings, where the parties' debate and the court decide. Aristotle indeed remembers that we must show ourselves in a certain appearance, "because Rhetoric exists to reach a judgment"9.

Plato $^{10}$, Aristotle $^{11}$, Cicero $^{12}$ and Quintilian ${ }^{13}$ remind us that the origins of Rhetoric are in Italy. Indeed, this method was born in Sicily in the fifth century BC.

Corax and his pupil Tisia abridged in a document in $465 \mathrm{BC}$ their argumentative techniques, used to defend the citizens of Syracuse who activated many legal proceedings to claim their lands expropriated by the regime of the tyrant Thrasybulus.

Corax was a disciple of Empedocles of Agrigento, which Aristotle considers the inventor of Rhetoric ${ }^{14}$, and he is remembered as the first organizer in Syracuse of a school of Legal Rhetoric. Among the first students of Corax there was Tisia that, in turn, became master of Lysias, the best lawyer of Athens in the Golden Age of Pericles.

In Latin culture, after Cato and Seneca, Quintilian said that the orator was vir bonus dicendi peritus ${ }^{15}$, suggesting us that lawyer is surely a man good at eloquence (dicendi peritus), but above all he's a man of honor

\footnotetext{
${ }^{9}$ Aristotle, Ars Rhetorica, 1377 b, The wORKs of AristotLe (W. D. Ross ed., Oxford: Oxford Clarendon Press 1912).

${ }^{10}$ Plato, Phaedrus, 273 C, Platonis Opera (J. Burnet ed., Oxford: Oxford University Press 1903).

${ }^{11}$ Aristotle, Sophistical Refutations, 34, 183 b 31, THE WORKS OF ARISTOTLE (W. D. Ross ed., Oxford: Oxford Clarendon Press 1912).

${ }^{12}$ Cicero, De Oratore, I 91-92; Brutus, 12, 46 (A. S. Wilkins ed., Oxford: Oxford Clarendon Press 1957).

${ }^{13}$ Quintilian, Institutio ORatoria, III, 1 (M. Winterbottom ed., Oxford: Oxford Clarendon Press 1970).

${ }^{14}$ Diogenes Laertius, Lives of Eminent Philosophers, VIII, 57 (R. D. Hicks ed., London, Heinemann, 1925).

${ }^{15}$ Quintilian, InSTITUTIO ORATORIA, XII, 1,1 (M. Winterbottom ed., Oxford: Oxford Clarendon Press 1970).
} 
(bonus).

In our age, in fact, eloquence and honor are rhetorical means that appear useful to defend by diligence the interest of the client as well as possible in a legal system.

If "speaking well" is "behaving well", then the morality of Rhetoric concerns the aim of a fair trial, which imposes a cooperation in the discussion of controversy. It compels all the participants to find a common point of view in the dispute by persuasive reasoning and good arguments.

The diligence of a counselor or a litigator is not a conceptual measure, but it is in the daily legal practice, where lawyers run the organized method of risk management or dispute settlement. Here, Rhetoric is an adversarial logic, by which every lawyer builds a well-argued solution of the case in defense of his client ${ }^{16}$.

There is a need to notice that Rhetoric has not to persuade, but to identify the means of persuasion. It's an interesting sentence of Aristotle, who added that Rhetoric is like medicine, whose function is not simply to make a man quite healthy, but to put him as far as may be on the road to health. Therefore, the Philosopher concludes that Rhetoric is not an exact science, but a faculty to provide arguments ${ }^{17}$.

Designed in its dialectical foundation, Rhetoric manages objections and, therefore, it enables the lawyers to distinguish the oppositions which arise every day in dealing with judges, clients, colleagues and third parties.

In fact, the discovery of Rhetoric arises in the Greek philosophy as the most suitable form of dispute settlement because of Dialectic, which constitutes the conceptual foundation of law in action.

Even today, Rhetoric justifies the culture and the technique for each lawyer.

Dialectic has been widely rediscovered in the contemporary theory of $\operatorname{argumentation}^{18}$, but without expressly recognizing its classical source. The

\footnotetext{
${ }^{16}$ P. Moro, L'Arte Della Scrittura GiURIDica. Retorica e Testo Difensivo (Pordenone: Libreria Al Segno Editrice 2016).

${ }^{17}$ Aristotle, Ars Rhetorica, 1356 a, The wORKs of ARISTOTLE (W. D. Ross ed., Oxford: Oxford Clarendon Press 1912).

${ }^{18}$ E. S. Toulmin, The Uses of ARgument (London-New York: Cambridge University Press 1958); H. P. Grice, Logic and Conversation, in The Logic OF Grammar (Dickenson, Encino 1975); R. AleXY, THEORIE DER JURISTISCHEN ARGUMENTATION (SuhrkampVerlag, Frankfurt am Main 1978); P. LORENZEN, DiALOGICHE LOGIK (Darmstadt: Wissenschaftliche Buchgesellschaft 1978); F. H. vaN EEMEREN \& R. GROOTENDORST, ARguMENTATION, COMMUNICATION, AND FALlaCiES. A PRAGMADialectical PersPective (Erlbaum, Hillsdale 1992); D. N. Walton \& E. C. W. Krabbe, COMMITMENT IN Dialogue. BASIC CONCEPTS OF INTERPERSONAL REASONING (Albany: State University of New York Press 1995); H. PraKKEN, LOGICAL TOOLS FOR MODELING LEGAL ARGUMENTS (Kluwer, Dordrecht 1997).
} 
ancient dialectic is an art of antilogy and mediation in a public debate, like trial, and it shows that justice is conflict ${ }^{19}$ and, at the same time, appeasement ${ }^{20}$.

Thus, Rhetoric is a method that allows not only to persuade another, but also to make a choice among alternative behaviors with an assumption of responsibility.

In the dialectical perspective, Rhetoric is founded on confutation: Plato says that confutation is a "purification" 21 , because the logical division has an ethical value when it educates through the debate, by dropping in contradiction one who believes to know the truth.

The zealous diligence is the lawyers' duty of loyalty, that is manifested primarily defending the client in a judicial dispute, potential or effective: Without a correct negotiation or a legal proceeding, the exercise of a persuasive and argued protection in a dispute could be neglected.

Sooner or later, a lawyer makes delivery of defense in a debate, regulated by an adversary system. Using rhetorical method, founded on dialectic, a good lawyer becomes really the voice of his client, defending his personal story and explaining his viewpoint.

In the Italian legislation, for instance, the abandon of the defensive activity is not permitted (art. 105 Criminal Procedure Code) and it is expression of the adversarial model; the violation of the duty of defense in the Court becomes a criminal offense in cases of unfaithful advocacy (art. 380 Penal Code) or infidelity by the contemporary defense on behalf of opposing parties (art. 381 Penal Code).

\section{FAIR PLAY AS ART OF SPORTSMANSHIP}

Currently, "fair play" is a term employed in various ways and in different situations (sports, ethics, business), but its conceptual roots are in the Western culture 22 .

The word "fair" is a medieval term and means "pleasant", "beautiful", "pure": Its first appearance in the 13th Century was in reference to the weather, but in the succeeding period, the adjective began to be used in the

\footnotetext{
${ }^{19}$ S. HAMPSHIRE, JusticE IS CONFLICT (Duckworth, London 1999).

${ }^{20} \mathrm{P}$. Moro, Il diritto come processo. Unaprospettivacritica per ilgiuristacontemporaneo, in IL DIRITTO COME PROCESSO. PRINCÌPI, REGOLE E BROCARDI PER LA FORMAZIONE CRITICA DEL GIURISTA (P. Moro ed., FrancoAngeli, Milano 2012).

${ }^{21}$ Plato, Sophist, 230 D-E, Platonis OPERA (J. Burnet ed., Oxford: Oxford University Press, 1903).

${ }^{22}$ A. GutTMAnN, SpORTS: THe First Five MillenNia (Amherst: University of Massachusetts Press 2004).
} 
figurative sense, encompassing the idea of rightness ${ }^{23}$.

This is the original sense of the word "sport", as activity that offers amusement or relaxation: The term derives from the Anglo-French disport or from the Old French desport or deport and means "pleasure, enjoyment, delight" ${ }^{\prime 24}$.

Therefore, the term "fair" is used as "beautiful", both aesthetically and morally, and it has been associated with sport since the mid-19th Century by the English amateur gentlemen and in the elite public schools, such as Eton and Rugby ${ }^{25}$.

Anyway, "fairness" is an idea implicitly present in the human relations and it is explicitly related to justice ${ }^{26}$ : "Fair" is a legal word used especially to identify the fair trial that is the due process of law, based on adversarial model.

The word "play" came from medieval English as activity that provides enjoyment, entertainment, amusement ${ }^{27}$. "Swordplay", referring to fencing, was its first use linked to physical activities.

"Play" is a legal word, too. In fact, "play" is the performance: Of an actor on the theater stage; of an athlete in the race; of a lawyer who gives his closing statement before a judge.

So, fair play is certainly an ethical principle, but it is mostly originally a legal value of sport, because it is based on the competitive dispute. Similarly to what happens in a fair trial, loyalty comes as equality of arms and symbolic dialogue even in sport activity ${ }^{28}$.

Therefore, fair play in sport is like a hearing in a fair trial.

This notion is described in the Declaration on the Fair Play of the International Council of Sport and Physical Education, held in 1976 and endorsed by the International Olympic Committee.

In the Declaration, fair play is not only "respect for the referees" but also "respect for the opponents, both when they win and when they lose, with the understanding that the opponent is a necessary partner in sport".

The Sports Code of Ethics, approved by the European Ministers responsible for Sport and published in 1993 by the Council of Europe, states that "fair play is defined as much more than playing within the rules" and "it

\footnotetext{
${ }^{23}$ T. F. HOAD, THE CONCISE OXFORD DictionARY OF ETYMOLOGY (Oxford University Press, Oxford 2003).

${ }^{24}$ ONLINE ETYMOLOGY Dictionary, http://www.etymonline.com/index.php.

${ }^{25}$ R. Renson, Fair Play: Its Origins and Meanings in Sport, 41 Kinesiology 1: 5-18 (2009).

${ }^{26}$ P. MCInTOSH, FAIR Play: ETHICS AND SPORT In EDUCATION 2 (Heinemann, London 1979).

${ }^{27}$ Oxford Reference, http://www.oxfordreference.com.

${ }^{28}$ C. E. Ashworth, Sport as a Symbolic Dialogue, The Sociology of Sport: A Selection of READINGS 40-46 (E. Dunning ed., London: Frank Cass 1971).
} 
incorporates the concepts of friendship, respect for others and sportsmanship" (para. 6).

The same norm establishes that "sports ethics is defined as a way of thinking, not just a way of behaving" and "it incorporates issues concerned with the elimination of cheating, the use of unfair strategies whilst respecting the rules $(\ldots)$ ".

Interestingly, in the European Code of sports, the ethics of fair play is an agonistic mindset, a sort of perception of relational dispute, not only a principle of respect of an abstract rule of honesty. In fact, in this sense, the violation of fair play hinders the competitive dialogue of sports action, which cannot be practiced in solitude, but it makes sense only in a contest of an athlete with another.

Roger Caillo is identified specifically in the competitive nature of the game (named agòn by the ancient Greeks), that is a conflict between two contenders in a specific field, in which each participant has an equal chance of winning and two opponents can compete within predefined limits by rules.

Callois says that agòn is motivated by the desire to improve themselves by challenging and overcoming opponents with the same skill. Thus, the competitive game cannot be played individually or against an automated system, but necessarily presupposes an interaction ${ }^{29}$.

The Council of Europe's Code indicates cheating, gamesmanship or doping as behaviours contrary to fair play, because these conducts are harmful and infringe the ethical principle of loyalty.

More specifically, the rules of competitive sports are "performative" (in the sense of J. L. Austin) $)^{30}$, since they are not activities whose goal is external, as making (in Ancient Greek poiein), but they realize their goal in the same purpose, as acting (in Ancient Greek práttein).

The sporting action is realizing in itself and it does not necessarily produce an external result, but takes place in the competition, that is in the set of criteria that characterize the techniques of each discipline. Moreover, a good race or a good athletic movement is behavioral assessment of the athletes beyond the simple result. So, fair play is an analogue judgment parameter in a legal sports issue.

In the contemporary philosophy of law, John Rawls has linked the principle of fair play to the concept of justice.

Rawls writes that "the public desire to execute good and fair play of the game must be regulative and effective if everyone's zest and pleasure are

\footnotetext{
${ }^{29}$ R. CALlois, Les JeUX ET LeS HOMmes. Le MASQue et Le VERTIGe (Gallimard, Paris 1958).

${ }^{30}$ J. L. Austin, How to Do ThingS with Words (Oxford: Clarendon Press 1962).
} 
not to languish" 31 .

Thus, the practice of sport is at the same time competitive and cooperative. In fact, as it happens in a legal proceeding, the possibility of playing the game is not founded on autonomy but on the sharing rules of cooperation of every participant to the dispute (referee, opponents, spectators).

At this point, it may be stated that fair play is a regulated action limiting every unfair advantage in sports in the same way of fairness in legal ethics. For instance, the abuse of competition and the abuse of process are similar and can cause harm to the whole system.

Moreover, apart from Rhetoric, another cornerstone of legal ethics is fair play, a performative principle based essentially on sportsmanship and competitive spirit.

In fact, in Ancient Greece, that was the homeland of Rhetoric, there was a close analogy between sporting competition and adversary trial: The agonistic contest and the legal proceeding were called by the same name of agòn by the ancient Greeks, first guardians of the Olympic Games.

The Ancient Games were disputed under divine protection of Zeus, judge of all conflicts, and in respect of the peaceful flame of Olympia: Every athlete may run to win fairly, but also learn the feeling of being a good loser, who takes defeat well. Perhaps, the individual feeling of a game within rules is a modern discovery ${ }^{32}$, but the idea of a battle of words in trial and game is really Greek.

The trial and the game belong to a common universe in which the opposition is an indispensable instrument of the way to achieve victory, through the same competitive aspects: The Court and the parties as referee and players of a dispute; the claim as a challenge; the discussion among the contenders as a duel; the appeal as revenge; the decision as a final result of the contest.

Athletes and lawyers may find in fair play a common opportunity and their own limit.

In the contemporary era, fair play and sportsmanship are reported in the oath pronounced by representatives of athletes, referees and coaches at the modern Olympic games; likewise, integrity and fair play are often mentioned in the attorney oath of new lawyers, who must hold fair conduct in the Court above anything else. For instance, in the Attorney Oath of

\footnotetext{
${ }^{31}$ J. RAwls, A THEORY OF Justice. Revised edition, 461 (Cambridge: Harvard University Press 1999).

${ }^{32}$ I. Weiler, Regel und Regelbruchbei den antiken Olympischen Spielen, THE OLYMPIC GAMES THROUGH THE AGES: GREEK ANTIQUiTy AND ITS IMPACT ON MODERN SPORT 55-64 (R. Renson et al. eds., Athens: Hellenic Sports Research Institute 1991).
} 
Admission to the Arkansas Bar (Rule VII, G) we read that "I will attempt to abide by the spirit of those ethical rules and precepts of honor and fair play" ${ }^{33}$.

Nowadays, employing fair play with clients, colleagues and the judge, lawyers can use the art of Rhetoric ethically as well as athletes: A perfect argument may fail if the audience does not trust the orator and it may help avoid authoritarian position or flawed reasoning.

In the Italian legislation, for example, the parties and their lawyers have a duty to behave in the Court with fairness and probity (art. 88 Civil Procedure Code). The duty of loyalty requires the parties to refrain from a conduct which, although formally correct, prevents interaction and, therefore, the full participation to communication and cooperation in the judicial debate.

This obligation, that is a form of fair play, is not identified with the correctness of the procedure aimed at achieving a rational result, but defines the interaction of the parties in an equal way, in order to seek for a common viewpoint in the dispute.

\section{LEGAL ETHICS BETWEEN ERISTIC AND GAMESMANSHIP}

Rhetoric and fair play hide two relevant distortions in the legal practice and in the sports competition: The eristic argumentation and the gamesmanship strategy.

In Ancient Greece, Eristic is the method of Sophists and consists in an argumentation that makes successful disputation an end in itself rather than approaching truth as a common viewpoint in the debate. Specifically, Eristic reduces the argumentation to an empty exercise and often becomes a specious form of charming reasoning, aimed to psychological conviction ${ }^{34}$.

Eristic is a negligent use of rhetorical technique in a legal debate, because the orator disregards the dialectic framework of trial, founded on the evidence organized by the adversary system. Thus, forgetting the confrontation means ignoring the client and his protection in a legal proceeding: The zealous lawyer cannot abuse of process because he needs a working trial.

In this perspective, the trial is serving the parties, not the judge.

A lawyer who neglects care and rigor of his professional mandate

\footnotetext{
${ }^{33}$ RULES GOVERNING AdMISSION TO THE ARKANSAS BAR (1963), https://courts.arkansas.gov/rulesand-administrative-orders/rules-governing-admission-to-the-bar.

${ }^{34}$ T. H. Irwin, Plato's Objection to the Sophists, in THE GREEK WORLD 568-590 (Anton Powell ed., Routledge, London 1995).
} 
inevitably infringes the duty of diligence that is a clause of legal contract and a principle of legal ethics.

On the other hand, in sports action, the so-called "strategic intentional foul" can be characterized as rule violations committed in order to be detected and to accept the corresponding sanction ${ }^{35}$. It is a tactical way of obtaining an advantage or subsequent benefit in the competition. This practice, legally invalid but ethically permitted, is not infrequent and it is even occasionally accepted by the players themselves, referees, judges, sports authorities and spectators.

For example, in basketball, the deliberate action of grabbing the rival shooter inside the three-point line is a strategic foul when happens at the end of a game and allows two free throws, in order to interrupt the opposing team's ball possession; in football, or soccer, a strategic foul the "selfbooking", that is a yellow card intentionally provoked against a contender in order to draw the following red card, thus completing the penalty-card cycle and the resulting suspension from a match against a minor rival.

Like in the civil disobedience, the strategic foul is admitted if the violation of rule is public and evident; if there is an axiological gap in the positive rules; if the player shows a special intention (the competitive advantage or the final victory) to go beyond the mere realization of the act.

The true strategic foul is different from every other tactical violation of rule that spoils the game, like cheating: It is "an attempt to gain an advantage by violating the shared interpretation of the basic rules (the ethos) of the parties engaged without being caught and held responsible for it" ${ }^{\prime 36}$.

In sports, this practice is an abuse of equality of arms and appears when the athletes play "spoiling the game". Here, they do not permit opponents the possibility of playing the competition, according to the formal rules but infringing its spirit. For instance, two football teams who both needed a point to not be sent to a minor league or to advance to the next round, mutually decided not to hurt one another and to tie the match.

Similarly, offensive tactics in a legal proceeding are not permitted to lawyers by the professional rules, because these conducts infringe the duty of diligence and fair play. However, defensive tactics of lawyers are generally admitted: The model of strategic intentional foul is an interesting evaluation parameter to understand the limits of the hard cases in legal ethics.

\footnotetext{
${ }^{35}$ J. L. Pérez Triviño, Strategic Intentional Fouls. Spoiling the Game and Gamesmanship, 6(1) SPORT, ETHICS AND PHILOSOPHY 67-77 (2012).

${ }^{36}$ S. LOland, Fair Play In SPORT. A Moral NORM SYSTEM 96 (Routledge, London and New York 2002).
} 
A literary example of this fuzzy condition of legal and sports ethics is pertinent.

In the judicial debate between Antonio and Shylock, in The Merchant of Venice of William Shakespeare, the trial concludes formally in a flawless way, but it seems somewhat unfair.

Portia (the lawyer who comes from the ancient Law School of Padua) uses the formal argument, like Shylock, noting that the pound of flesh must be correct and it must not spill a drop of blood. Indeed, having attempt on the life of a Venetian citizen, the plaintiff Shylock must give his property to the City and to the offended Antonio ${ }^{37}$.

This sort of parallel inversion of essence and appearance can remember the rhetorical chiasmus in the conclusion of the first scene of Macbeth: "Fair is foul, and foul is fair: Hover through the fog and filthy air",38.

\section{CONCLUSION}

The obligation of loyalty imposes to the lawyers a rhetorical dialogue in every legal proceeding and it prescribes to keep the relationship between opponents on a real level of equity, but avoiding the lie.

The principle of fair play implies the right to remain silent, not the right to lie. In the modern philosophy, Immanuel Kant writes that "a lie always harms another; if not some other human being, then it nevertheless does harm to humanity in general" 39 . In fact, the lie deceives the truth because it violates the ethics of dialogue, which is the constitutive essence of human being.

In conclusion, lawyers are like athletes: They follow legal ethics in action. Using Rhetoric and fair play, the lawyer is "a good man speaking well" (vir bonus dicendiperitus, in the words of the ancient orators), if his knowledge and his skills are managed for the advantage of the client in a fair proceeding.

Just as the good athlete defends the team colors acting loyally in a race, so the good lawyer protects the dignity of his client not only by a diligent technique but also by fair tactics. The famous Latin statement contains a twofold and mutual significance: Only the good lawyer is a valuable rhetorician; only the good rhetorician is a valuable lawyer.

\footnotetext{
${ }^{37}$ W. Shakespeare, The Merchant of Venice, IV, 1, THE ARDEN SHAKESPEARE COMPLETE WORKS (Richard Proudfoot et al. eds., Bloomsbury, London 2011).

${ }^{38}$ W. Shakespeare, Macbeth, I, 1, THE ARDEN SHAKESPEARE COMPLETE WoRKs (Richard Proudfoot et al. eds., Bloomsbury, London 2011).

${ }^{39}$ I. Kant, On a Supposed Right to Lie Because of Philanthropic Concerns, in BERLINISCHE BLAETTER (Berlin: Berlin Press 1799).
} 